\title{
Actions of $1,25(\mathrm{OH})_{2}$-vitamin $D_{3}$ on the cellular cycle depend on VDR and p38 MAPK in skeletal muscle cells
}

\author{
Ana P Irazoqui, Ricardo L Boland and Claudia G Buitrago \\ INBIOSUR - CONICET, Departamento de Biología, Bioquímica and Farmacia, Universidad Nacional del Sur, \\ San Juan 670, 8000 Bahía Blanca, Argentina
}

Correspondence should be addressed to C G Buitrago

Email

cbuitrag@criba.edu.ar

\begin{abstract}
Previously, we have reported that $1,25(\mathrm{OH})_{2}$-vitamin $\mathrm{D}_{3}(1,25 \mathrm{D})$ activates $\mathrm{p} 38$ MAPK (p38) in a vitamin $\mathrm{D}$ receptor (VDR)-dependent manner in proliferative $\mathrm{C} 2 \mathrm{C} 12$ myoblast cells. It was also demonstrated that $1,25 \mathrm{D}$ promotes muscle cell proliferation and differentiation. However, we did not study these hormone actions in depth. In this study we have investigated whether the VDR and $\mathrm{p} 38$ participate in the signaling mechanism triggered by 1,25D. In C2C12 cells, the VDR was knocked down by a shRNA, and p38 was specifically inhibited using SB-203580. Results from cell cycle studies indicated that hormone stimulation prompts a peak of S-phase followed by an arrest in the G0/G1-phase, events which were dependent on VDR and p38. Moreover, 1,25D increases the expression of cyclin D3 and the cyclin-dependent kinase inhibitors, p21 ${ }^{\text {Waf1/Cip1 }}$ and p27 ${ }^{\text {Kip1 }}$, while cyclin D1 protein levels did not change during G0/G1 arrest. In all these events, p38 and VDR were required. At the same time, a 1,25D-dependent acute increase in myogenin expression was observed, indicating that the G0/G1 arrest of cells is a pro-differentiative event. Immunocytochemical assays revealed co-localization of VDR and cyclin D3, promoted by 1,25D in a p38-dependent manner. When cyclin D3 expression was silenced, VDR and myogenin levels were downregulated, indicating that cyclin D3 was required for 1,25D-induced VDR expression and the concomitant entrance into the differentiation process. In conclusion, the VDR and p38 are involved in control of the cellular cycle by 1,25D in skeletal muscle cells, providing key information on the mechanisms underlying hormone regulation of myogenesis.
\end{abstract}
Key Words
- vitamin D
- signal transduction
- muscle
- cell cycle

Journal of Molecular Endocrinology (2014) 53, 331-343

\section{Introduction}

Recruitment of cells in G0/G1 stage is a pre- and pro-differentiation arrest of skeletal muscle myoblasts, necessary to the subsequent development of myotubes (Mercer et al. 2005). For cell cycle progression, the cellular exit from G1-phase and entry into S-phase require formation and activation of cyclin-cyclin-dependent kinases (CDKs) complexes. The CDK inhibitors (CKI), $\mathrm{p} 21^{\text {Waf1/Cip1 }}$ and $27^{\mathrm{Kip} 1}$, can block both the cyclin/CDK activity and subsequent phosphorylation of pRb family proteins, resulting in G1-phase arrest (Chellappan et al. 1998). Specifically, in C2C12 skeletal muscle cells, the expression of most cyclins is downregulated at the onset of differentiation, as cells arrest in the G0/G1-phase of the cell cycle (Jahn et al. 1994, Wang \& Nadal-Ginard 1995). However, cyclin D3 is paradoxically upregulated during muscle differentiation, showing to be a key player in

Published by Bioscientifica Ltd. 
myogenesis (Kiess et al. 1995, Rao \& Kohtz 1995). It is relevant that cyclin D3 is involved in the permanent withdrawal of $\mathrm{C} 2 \mathrm{C} 12$ myoblasts from the cell cycle (Cenciarelli et al. 1999) and an increase in its expression in proliferating myoblasts causes early myogenesis (Gurung \& Parnaik 2012). The role of cyclin D1 in the C2C12 cell cycle is opposite to that of cyclin D3, i.e. cyclin D1 is highly expressed in proliferating cells and its expression is markedly reduced after 1 day on differentiation medium (Clemente et al. 2005). With respect to CKIs, p21 $1^{\text {Waf1/Cip1 }}$ plays an important role inhibiting the progression of the cellular cycle in $\mathrm{C} 2 \mathrm{C} 12$ cells (Davidovic et al. 2013), and an active role for $\mathrm{p} 27^{\mathrm{Kip} 1}$ at an early stage of differentiation has been established (Messina et al. 2005).

P38 MAPK (p38), a key signaling pathway involved in skeletal muscle differentiation, is a member of the MAPKs super family (Zetser et al. 1999). Inhibition of p38 activity abrogates myoblast differentiation and fusion (Lluís et al. 2005). Of the four isoforms of the p38 family described, it was reported that p38 $\alpha, \beta$, and $\gamma$ are all required for myogenic differentiation in $\mathrm{C} 2 \mathrm{C} 12$ cells (Wang et al. 2008). The inhibitor SB-203580 has been successfully used to study the functional roles of p38 $\alpha$ and $\beta$ because it selectively inhibits these isoforms without affecting the $\gamma$ and $\delta$ isoforms (Kumar et al. 1997). Studies using this inhibitor implicated p38 $\alpha$ and $\beta$ in the promotion of skeletal muscle differentiation in vitro (Cuenda \& Cohen 1999). P38 facilitates withdrawal of myoblasts from the cell cycle, allowing the beginning of differentiation (Lee et al. 2002). Moreover, terminal muscle cell differentiation is dependent on a functional p38 MAPK pathway and the expression of CKIs, p2 $1^{\text {Waf1/Cip1 }}$ and $\mathrm{p} 27^{\text {Kip } 1}$, is affected in C2C12 cells lacking MKK3, the direct kinase activator of p38 (Cabane et al. 2003). Several novel p38 MAPK-target genes, including CCDN3, are required for myogenin expression. It is relevant that cyclin D3 expression in memory B cells has also been shown to be dependent on p38 (Ertesvag et al. 2007). In C2C12 cells, cyclin D3 is regulated by p38 $\beta$ and it is required for myogenic differentiation (Wang et al. 2008).

The steroid hormone $1,25(\mathrm{OH})_{2}$-vitamin $\mathrm{D}_{3}(1,25 \mathrm{D})$ is involved in myogenesis events and its biological actions on skeletal muscle cells have been a subject of interest for more than 20 years. The effects of $1,25 \mathrm{D}$ vary according to the type of skeletal muscle cells, stage of proliferation or differentiation, and culture (serum) condition employed. We have previously obtained data indicating that $1,25 \mathrm{D}$ modulates proliferation and differentiation of $\mathrm{C} 2 \mathrm{C} 12$ cells (Buitrago et al. 2012). However, there are no reports about the effects of $1,25 \mathrm{D}$ on cellular cycle phases, cyclins, and CKIs in skeletal muscle cells, nor on the role of the vitamin D receptor (VDR) and p38 in hormone-dependent events. $1,25 \mathrm{D}$ exerts most of its biological actions through VDR, which acts as a transcription factor (MacDonald et al. 2001). VDR bound to $1,25 \mathrm{D}$ and retinoid $X$ receptor interacts with vitamin D-response elements (VDREs) in the promoters of vitamin D target genes (Aslam et al. 1999). In this regard, it is known that the VDR interacts with co-repressors as part of the transcriptional mechanisms by which myoblast arrest is induced (Campbell 2014). However, it is uncertain whether the binding of an agonist to the VDR allows RXR to bind the co-repressors. There are several proposals regarding the assembly of molecular machines during the cell cycle, involving both transcriptional and post-translational control of the dynamics of biological systems (Jensen et al. 2006). Recently, Jian et al. (2005) have reported that cyclin D3 interacts with VDR and regulates its transcriptional activity. This interaction was strengthened by treatment with 1,25D. However, the relationship between VDR and cyclin D3 was not studied in depth. In this work, we show for first time, to our knowledge, that silencing of cyclin D3 affects VDR and myogenin expression induced by a physiological dose of $1,25 \mathrm{D}$ and p38 inhibition conditions co-localization of VDR with cyclin D3 in skeletal muscle cells. Moreover, we explore the involvement of VDR in the action of $1,25 \mathrm{D}$ on the cellular cycle and evaluate the contribution of p38 in hormonetriggered pro-differentiative events in skeletal muscle cells.

\section{Materials and methods}

\section{Materials}

1 $\alpha, 25$-dihydroxyvitamin $\mathrm{D}_{3}$ was purchased from Sigma Chemical Co. Fetal bovine serum (FBS) was from Natocor (Villa Carlos Paz, Argentina). Free-phenol red DMEM was from US Biological, Inc. (Salem, MA, USA). Anti-cyclin D3 (\#2936), anti cyclin D1 (\#2926), anti-p21 Waf1/Cip1 (\#2946), and anti-p27 ${ }^{\mathrm{Kip} 1}$ (\#2552) antibodies were purchased from Cell Signaling Technology, Inc. (Beverly, MA, USA). Anti-myogenin (sc-12732), anti-VDR (sc-1008) and antitubulin antibodies (sc-73242), HRP-conjugated secondary antibodies (anti-rabbit, sc-2004, and anti-mouse, sc-2005), and siRNA against cyclin D3 mRNA (sc-35137) were purchased from Santa Cruz Biotechnology. Alexa Fluor 488 (green) goat anti-rabbit IgG (A-11008) and Alexa fluor 647 (red) goat anti-mouse-conjugated antibodies (A-21236) are obtained from Molecular Probes (Eugene,

Published by Bioscientifica Ltd. 
OR, USA). The inhibitor SB-203580 was from TOCRIS (Tocris Bioscience, Bristol, UK). The Super Signal CL-HRP substrate system for ECL was from Perkin Elmer (Boston, MA, USA). The WT C2C12 cell line was obtained from the American Type Culture Collection (ATCC, Manassas, VA, USA). Puromycin was from Invitrogen. The plasmid to knock down the VDR was pLKO.1, clone ID TRCN0000027101 (Open Biosystems, Huntsville, AL, USA). Lentivirus particles containing a pLKO.1 vector with the sequences encoding a shRNA against VDR were kindly provided by Dr V Gonzalez Pardo, Universidad Nacional del Sur (Bahia Blanca, Argentina).

\section{Lentivirus infection and selection}

To generate a stable (long-term) knockdown of $V D R$ gene expression in the $\mathrm{C} 2 \mathrm{C} 12$ cell line, these cells were infected with lentivirus particles containing a pLKO.1 vector with the sequences encoding a shRNA against mouse VDR. This plasmid also has a gene encoding puromycin resistance, thereby addition of this antibiotic allowed us to select cells stably expressing shRNA against VDR (C2C12-VDR). We have described the protocol in a previous publication (Buitrago et al. 2013).

\section{Cell culture and synchronization}

The mouse skeletal myoblasts $\mathrm{C} 2 \mathrm{C} 12 \mathrm{WT}$ and $\mathrm{C} 2 \mathrm{C} 12$ (-VDR) grown in low-glucose DMEM supplemented with $10 \%$ FBS and $2 \%$ antibiotics (penicillin and streptomycin), $1 \%$ antimycotic (nistatine) solution with or without puromycin $(2 \mu \mathrm{g} / \mathrm{ml})$, were employed. The cells were not allowed to exceed $70 \%$ of confluence during passages and were discarded after ten passages (30 days), to minimize depletion of myoblasts in culture. We performed all the experiments independently at different passages (between the first and tenth passages). The cells were seeded at an appropriate density $\left(100000\right.$ cells $\left./ \mathrm{cm}^{2}\right)$ in Petri dishes (100 mm diameter) with growth medium and cultured at $37^{\circ} \mathrm{C}$ under a humidified atmosphere of $95 \%$ air $/ 5 \% \mathrm{CO}_{2}$. Under these conditions, myoblasts divide within the first $48 \mathrm{~h}$. The subconfluent cells were rendered quiescent by placing them in DMEM containing $2 \%$ FBS for $16 \mathrm{~h}$ (starved). The cells, cultured for 2 days (proliferative stage) and starved as indicated, were used for the treatments described in the Results section.

\section{Cell cycle analysis by flow cytometry}

C2C12 WT and C2C12 (-VDR) cells were dispersed by trypsinization, washed twice with PBS, and then resuspended in $1 \mathrm{ml}$ PBS. After $24 \mathrm{~h}$ fixation in absolute ethanol, cells were suspended in PBS containing 5\% Tween detergent. The fixed and permeabilized cells were pelleted and re-suspended with $500 \mu \mathrm{l}$ of RNase-propidium iodide mix (BD Biosciences, San Diego, CA, USA) for $30 \mathrm{~min}$. The fluorescence of DNA was measured using a flow cytometer (Becton-Dickinson FACS Calibur) and the cell distribution in different phases of the cellular cycle was analyzed by computer software (CELLQuest PRO, Becton-Dickinson, San Jose, CA, USA).

\section{Electrophoresis and western blotting}

Following treatment, the cells were lysed, the clarified lysates were resolved by one-dimensional SDS-PAGE and then transferred to Immobilon P membranes as previously described (Morelli et al. 2001). Standard samples were included in the first lane of all gels to make between-blot comparisons possible (data not shown). The membranes were then probed with specific primary antibodies. After incubation with peroxidase-conjugated secondary antibodies, the membranes were visualized by ECL captured by chemiluminescence film. The antibodies bound to proteins were then stripped and the membranes were reprobed with anti-tubulin or anti-p38 $\alpha$ antibodies to compensate for differences in gel loading. The films were scanned by a HP densitometer to quantify bands signals by the ImageJ software program.

\section{Immunocytochemistry and confocal microscopy}

C2C12 cells were grown on glass coverslips and after treatments were immediately washed in cold PBS solution and fixed in methanol $\left(\right.$ at $\left.-20^{\circ} \mathrm{C}\right)$ for $20 \mathrm{~min}$, a process which also permeabilized the cells. Non-specific sites were blocked with 5\% BSA in PBS for $1 \mathrm{~h}$. The samples were then incubated overnight at $4{ }^{\circ} \mathrm{C}$ with the appropriate primary antibody (anti-VDR or anti-cyclin D3 antibodies) prepared in $2 \%$ BSA in PBS. After washing with PBS, the samples were incubated with secondary anti-rabbit or anti-mouse fluorophore-conjugated antibodies $(1 \mathrm{~h}$, room temperature). The samples were examined using a Leica confocal laser microscope.

\section{Silencing of cyclin D3 by transfection of siRNA}

Six-well tissue culture plates with $2 \times 10^{5}$ cells/well starved in antibiotic-free medium supplemented with $2 \%$ FBS were used for transfection. After $6 \mathrm{~h}$, the transfection mixture was removed and replaced with a normal growth medium. The cells were incubated for an additional $18 \mathrm{~h}$

Published by Bioscientifica Ltd 
until used for treatments. The protocol followed is in accordance with manufacturer's instructions (Santa Cruz Biotechnology).

\section{Statistical analysis}

The results were expressed as mean \pm s.D. The differences between means values were analyzed using Student's $t$-test (Snedecor \& Cochran 1967). The differences were considered statistically significant when $P \leq 0.05$.

\section{Results}

\section{Cell cycle progression of C2C12 muscle cells after serum stimulation}

We considered it necessary to characterize the time course of the cell cycle in C2C12 WT and C2C12 (-VDR) cells which had not, to our knowledge, been previously reported, following the procedure described for vascular smooth muscle cells (Nakano et al. 2005). To that end, all cells were deprived of FBS for $16 \mathrm{~h}$ to synchronize the cultures at the time in which $85 \%$ of cells were growtharrested in the G0/G1-phase (data not shown). Then, the arrested cells were stimulated using 10\% FBS for different times $(6,12,18$, and $24 \mathrm{~h})$ and analyzed by flow cytometry. Figure 1 shows that in both C2C12 WT and C2C12 (-VDR) lines, approximately $90 \%$ of cells were in the G0/G1-phase after $6 \mathrm{~h}$ of serum stimulus, the progression of cell cycle from G1- to S-phase then takes place and a S-phase peak was observed at $12 \mathrm{~h}$. After completion of the S-phase, a $\mathrm{G} 2 / \mathrm{M}$-phase increase is observed at $18 \mathrm{~h}$. One round of the cell cycle seemed to be completed at $24 \mathrm{~h}$, when most of the cells were again in G0/G1-phase, diminishing the percentage of cells in S-phase. This cell cycle pattern was similar in C2C12 WT and C2C12 (-VDR) cells.

\section{Hormone stimulation of $\mathrm{C} 2 \mathrm{C} 12$ muscle cells prompts a VDR-dependent S-phase peak followed by an arrest in the G0/G1-phase: the activation of p38 MAPK is required in 1,25D-induced G0/G1 arrest}

We evaluated the role of the VDR in the distribution of myoblasts in the different phases of the cell cycle in the C2C12 WT and C2C12 (-VDR) lines treated with $1 \mathrm{nM}$ $1,25 \mathrm{D}$ for 6,12 , and $24 \mathrm{~h}$. As explained in the Materials and methods section, subconfluent cells were rendered quiescent by placing them in DMEM containing $2 \% \mathrm{FBS}$ for $16 \mathrm{~h}$ (starved). Flow cytometry analyses were then carried out as in Fig. 1. In C2C12 WT cells, it was evidenced that the hormone promotes an increase in the S-phase peak at $12 \mathrm{~h}$. This was followed by a significant recruitment of cells in the G0/G1-phase at $24 \mathrm{~h}$. In C2C12 (-VDR) myoblasts, where the VDR is not significantly expressed, the percentages of cells in the S-phase at $12 \mathrm{~h}$ were lower than in WT cells and remained unchanged at $24 \mathrm{~h}$. Moreover, the number of cells arrested in the G0/G1phase at $24 \mathrm{~h}$ was significantly smaller than in the $\mathrm{C} 2 \mathrm{C} 12$ WT line expressing the VDR (Fig. 2A). These results for the first time, to our knowledge, indicate the involvement of the VDR in modulation of skeletal muscle cell cycle by the hormone. It is noteworthy that these data indicate that the VDR is necessary to induce cell cycle arrest, which is essential for myogenic differentiation.

P38 activation is required for the withdrawal of myoblasts from the cell cycle that precedes muscle differentiation (Lee et al. 2002). Thereby, in order to establish if p38 activation is a requisite in the G0/G1-phase arrest promoted by $1,25 \mathrm{D}$ in $\mathrm{C} 2 \mathrm{C} 12$ cells, we investigated changes in cellular phases by flow cytometry in presence of the p38 inhibitor SB-203580 $(10 \mu \mathrm{M})$. Figure 2B shows that the 1,25D-induced G0/G1-phase arrest of cells is abrogated when p38 is inhibited, indicating that the hormone employs the p38 pathway to promote the onset of muscle differentiation.

\section{The VDR and p38 MAPK are required in 1,25D-induced cyclin D3 expression in C2C12 muscle cells}

It is well established that the expression of cyclin D1 rapidly declines in myoblasts induced to differentiate, arrested in G0/G1-phase, whereas cyclin D3 is induced at the transcriptional and post-translational levels (Kiess et al. 1995). We studied cyclin D3 and cyclin D1 expression in C2C12 cells stimulated by 1,25D. Figure $3 \mathrm{~A}$ and B shows that the hormone increases cyclin D3 protein levels at $24 \mathrm{~h}$ of treatment, whereas no significant changes were observed in cyclin D1 in C2C12 WT cells. The increment in cyclin D3 induced by 1,25D was abolished in C2C12 (-VDR) cells, indicating that the VDR mediates hormone upregulation of cyclin D3 protein levels. No changes in the expression of the two cyclins were detectable at $18 \mathrm{~h}$ of hormone treatment.

The involvement of $\mathrm{p} 38$ activity in cyclin D3 expression was also investigated. Our data reveal that $1,25 \mathrm{D}$ activates p38 at $24 \mathrm{~h}$ and this effect is successfully abrogated by the use of $10 \mu \mathrm{M}$ of SB-203580. It is of relevance that the results show that SB-203580 abolishes the expression of cyclin D3 induced by the hormone at $24 \mathrm{~h}$, providing evidence that it is dependent on p38 activation (Fig. 3C and D).

Published by Bioscientifica Ltd. 
C2C12 WT stimulated with FBS
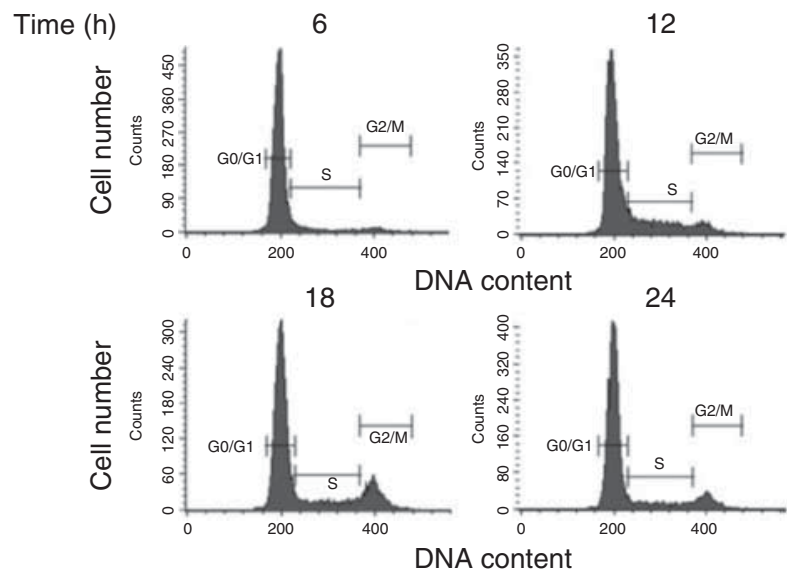

B
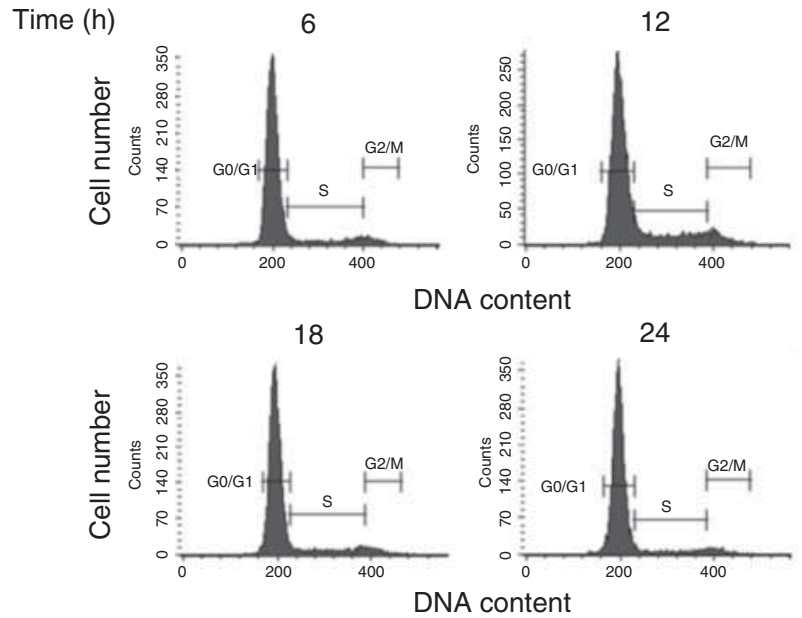

Figure 1

Cell cycle progression of C2C12 WT and C2C12-VDR muscle cells after serum stimulation. $\mathrm{C} 2 \mathrm{C} 12$ WT cells and $\mathrm{C} 2 \mathrm{C} 12$ cells lacking VDR expression (C2C12VDR) were starved for $16 \mathrm{~h}$ and thereafter stimulated with $10 \%$ FBS for $6,12,18$, and $24 \mathrm{~h}$. At each time indicated, cells were trypsinized, stained

\section{Induction of CKIs p21 ${ }^{\text {Waf1/Cip } 1}$ and $p 27^{\text {Kip } 1}$ by $1,25 \mathrm{D}$ occurs in a VDR- and p38 MAPK-dependent manner in C2C12 muscle cells}

$\mathrm{P} 21^{\text {waf1/Cip } 1}$ and $\mathrm{p} 27^{\mathrm{kip} 1}$ are CKIs that are overexpressed when $\mathrm{C} 2 \mathrm{C} 12$ myoblasts withdraw from the cell cycle and commit to muscle fiber differentiation (Andres \& Walsh 1996, Franklin \& Xiong 1996). The involvement of the VDR in the expression of both CKIs by $1,25 \mathrm{D}$ was investigated. Figure $4 \mathrm{~A}, \mathrm{~B}$, and $\mathrm{C}$ shows that the hormone markedly increases CKIs $\mathrm{p} 21^{\text {waf1/Cip } 1}$ and p2 $7^{\text {kip1 }}$ levels in C2C12 WT cells at $24 \mathrm{~h}$ of stimulation,

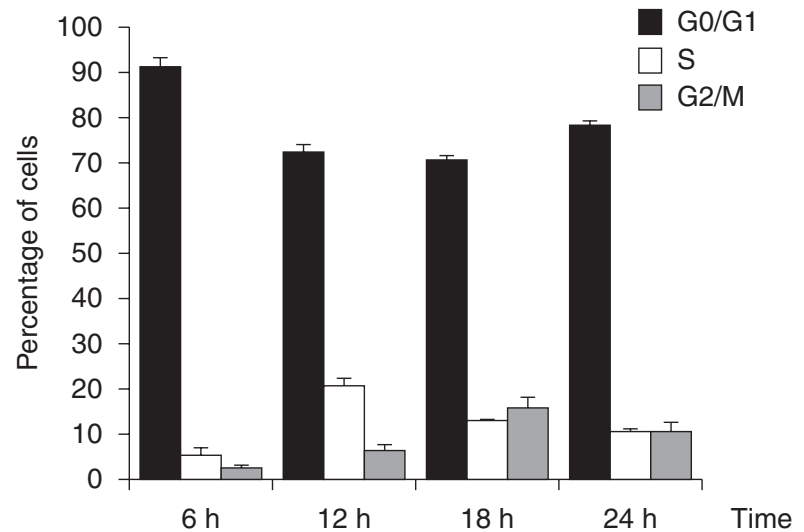

with propidium iodide, and DNA contents were measured by flow cytometry. C2C12 WT (A) and C2C12-VDR cells (B): (left panels) representative DNA histograms and (right panels) quantifications of DNA histograms showing percentages of cells in G0/G1-, S- and G2/M-phases.

the time corresponding to the G0/G1-phase arrest, and increase in cyclin D3 observed previously. As expected, the effects of the steroid on both CKIs were not evidenced when VDR expression was suppressed in C2C12 (-VDR) cells.

Taking into account previous results indicating the involvement of p38 in cell growth modulation (Kim et al. 2002, Miura et al. 2005), the involvment of p38 in the effects of $1,25 \mathrm{D}$ on CKIs p $21^{\text {waf } 1 / \text { Cip } 1}$ and p2 $7^{\text {kip } 1}$ expression was evaluated. The use of SB-203580 proved that activation of $\mathrm{p} 38$ is required for the increase of $\mathrm{p} 21^{\mathrm{waf} 1 / \mathrm{Cip} 1}$ and $\mathrm{p} 27^{\mathrm{kip} 1}$ levels in response to the hormone (Fig. 4D and E). The VDR and p38-dependent rise of 


\begin{tabular}{l|l|l|c|c|} 
Research & A P IRAZOQUI and others & $\begin{array}{l}1,25 \mathrm{D} \text { actions in C2C12 cell } \\
\text { myogenesis }\end{array}$ & $\mathbf{5 3 : 3}$
\end{tabular}
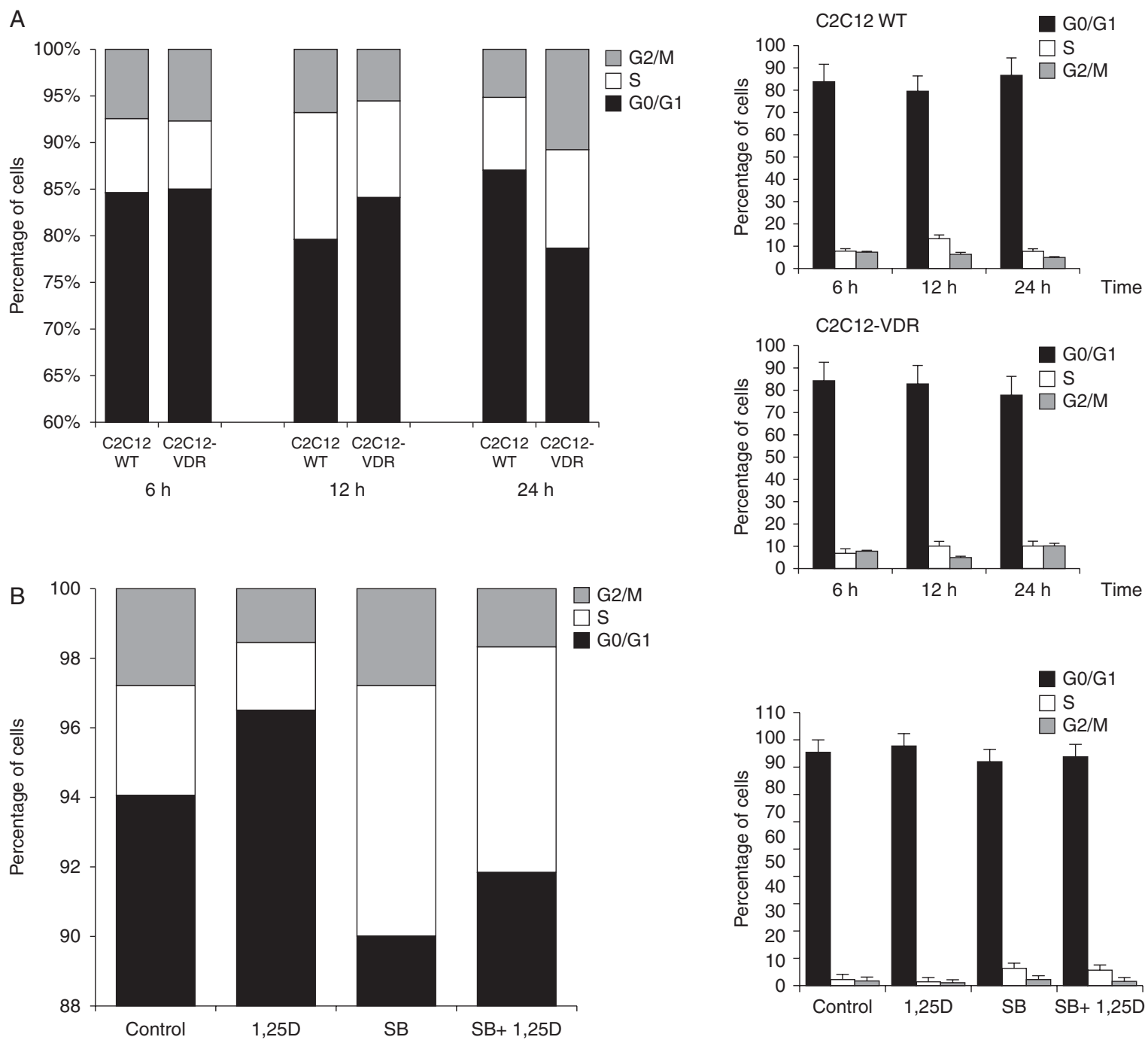

Figure 2

$1,25 \mathrm{D}$ treatment promotes redistribution of cells in the $\mathrm{C} 2 \mathrm{C} 12$ cellular cycle in a VDR- and p38-dependent manner. (A) C2C12 WT and C2C12-VDR cells

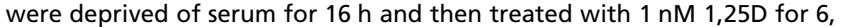
12 , and $24 \mathrm{~h}$. At each time indicated, cells were trypsinized, stained with propidium iodide, and DNA contents were measured by flow cytometry, in three independent experiments. The panel shows the quantification of the DNA histograms with percentages of WT and -VDR cells in G0/G1-, S- and G2/M-phases in graphs with combined bars (left) and independent bars of

$\mathrm{p} 21^{\text {waf1/Cip1 }}$ and $\mathrm{p} 27^{\mathrm{kip} 1}$ at G0/G1-phase arrest of cells further supports the proposal that 1,25D induces muscle cell differentiation via the VDR and also involves p38.

\section{The VDR and p38 MAPK are involved in 1,25D-promoted myogenin expression in $\mathrm{C} 2 \mathrm{C} 12$ muscle cells}

It is well established that myogenin expression is indispensable as the first step in the differentiation of myoblasts,

each cellular line to show S.D. (right). (B) C2C12 WT cells were deprived of serum for $16 \mathrm{~h}$, preincubated with $10 \mu \mathrm{M}$ of p38 inhibitor SB-203580, and then treated with $1 \mathrm{nM} 1,25 \mathrm{D}$ for $24 \mathrm{~h}$. The cells were trypsinized, stained with propidium iodide, and DNA contents were measured by flow cytometry, in three independent experiments. The panel shows the quantification of the DNA histograms with percentages of WT cells in G0/G1-, S-, and G2/M-phases in graphs with combined bars (left) and independent bars (right).

which is followed by their withdrawal from the cell cycle (Andres \& Walsh 1996). Since 1,25D promotes G0/G1-phase arrest of $\mathrm{C} 2 \mathrm{C} 12$ cells, changes in myogenin protein levels were then investigated. Figure $5 \mathrm{~A}$ and $\mathrm{B}$ shows that $1,25 \mathrm{D}$ induces a marked increase in myogenin expression at $24 \mathrm{~h}$, which is still evident at $72 \mathrm{~h}$, in C2C12 WT cells. Noteworthy, myogenin levels are undetectable in C2C12-VDR cells at all times studied, indicating that the VDR is required for the hormone-dependent synthesis of 
A

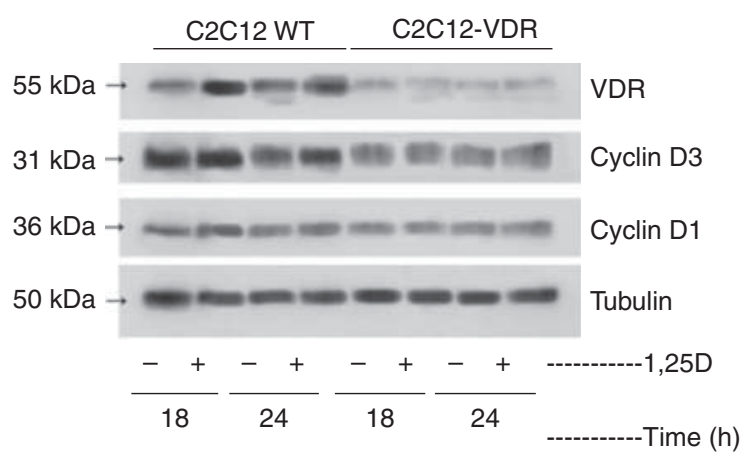

C

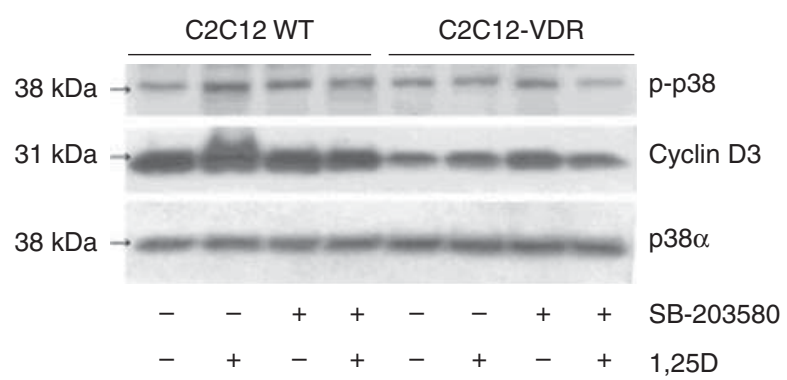

B $\quad$ Cyclin D3

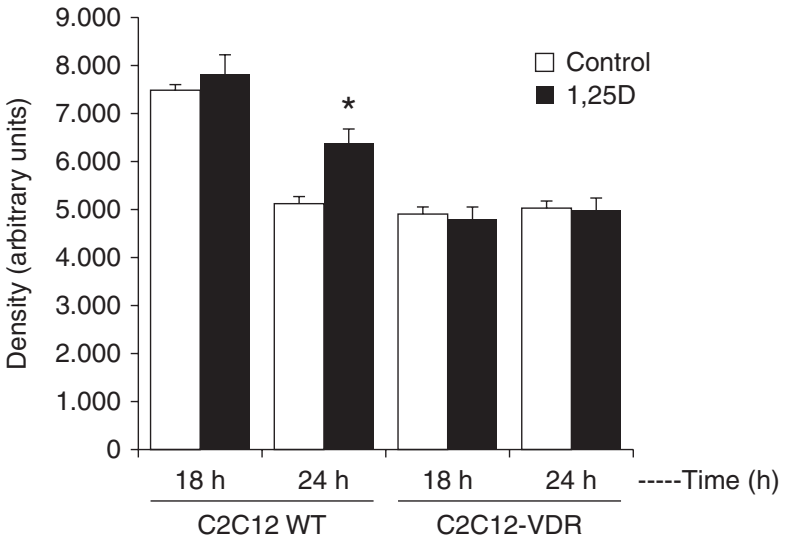

D

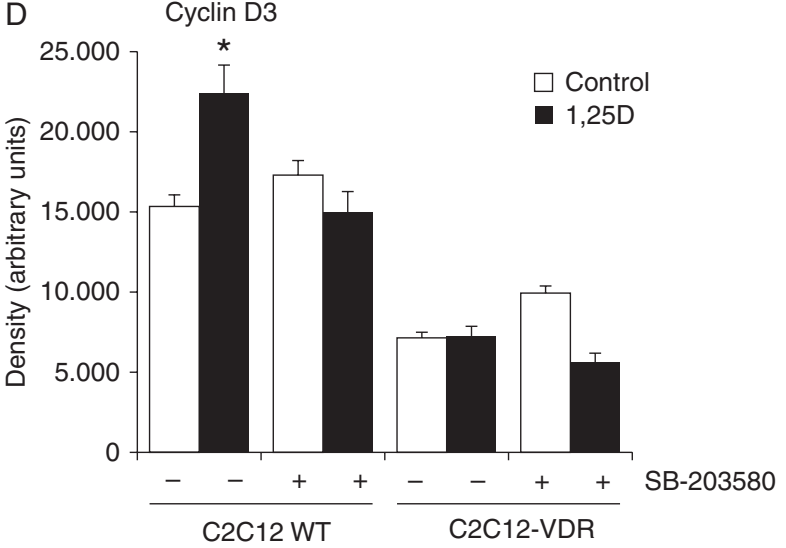

\section{Figure 3}

The VDR and p38 MAPK participate in the increase in cyclin D3 expression in response to the hormone in muscle cells. C2C12 WT and C2C12-VDR cells were treated with $1 \mathrm{nM} 1,25 \mathrm{D}$ or vehicle $(0.001 \%$ isopropanol) for 18 and $24 \mathrm{~h}$. Western blotting analysis was carried out using anti-VDR, anti-cyclin D3, and anti-cyclin D1 antibodies. The blotted membranes were reprobed with anti-tubulin antibody in order to ensure equal loading of gels. (A) Representative immunoblots from three independent experiments. (B) Quantifications by scanning volumetric densitometry of blots from the three experiments showing mean \pm s.D. of cyclin D3 protein levels. ${ }^{\star} P<0.05$ with respect to the corresponding control. (C and D) C2C12 WT and

this early differentiation marker protein. Moreover, it was also evidenced that myogenin expression triggered by $1,25 \mathrm{D}$ is dependent on p38 activation (Fig. 5C and D).

\section{VDR co-localizes with cyclin D3 in 1,25D-stimulated C2C12 muscle cells only when p38 MAPK is activated}

As described previously, we showed that VDR expression is required for $1,25 \mathrm{D}$-dependent upregulation of cyclin D3 in C2C12 cells. The interaction of cyclin D3 with VDR has been previously reported only by Jian et al. (2005) using another cell type. In this work, confocal immunocytochemistry was
C2C12-VDR cells were preincubated with $10 \mu \mathrm{M}$ SB-203580 and then treated with $1 \mathrm{nM} \mathrm{1,25D}$ or vehicle (0.001\% isopropanol) for $24 \mathrm{~h}$. Western blotting analysis was carried out using anti-P-p38 MAPK, which recognizes only activated p38, and anti-cyclin D3. The blotted membranes were reprobed with anti-p38 $\alpha$ antibody in order to ensure equal loading of gels. (C) Representative immunoblots from three independent experiments. (D) Quantifications by scanning volumetric densitometry of blots from the three experiments showing mean \pm s.D. of cyclin D3 protein levels. $* P<0.05$ with respect to the corresponding control.

used to examine the intracellular localization of VDR and cyclin D3 in C2C12 cells committed to differentiation. In WT cells stimulated with 1,25D for $24 \mathrm{~h}$, confocal images confirm that the hormone induces VDR expression and increases cyclin D3 protein levels (Fig. 6D and E vs A and B). There was no significant co-localization of VDR and cyclin D3 under basal conditions (Fig. 6C). 1,25D treatment promotes nuclear co-localization of VDR with cyclin D3 and also a re-distribution of VDR, observable in the plasma membrane region (Fig. 6F). Interestingly it was observed that WT C2C12 cells treated only with SB-203580 displayed significantly diminished VDR and cyclin D3-related fluorescence, indicating

Published by Bioscientifica Ltd 
A

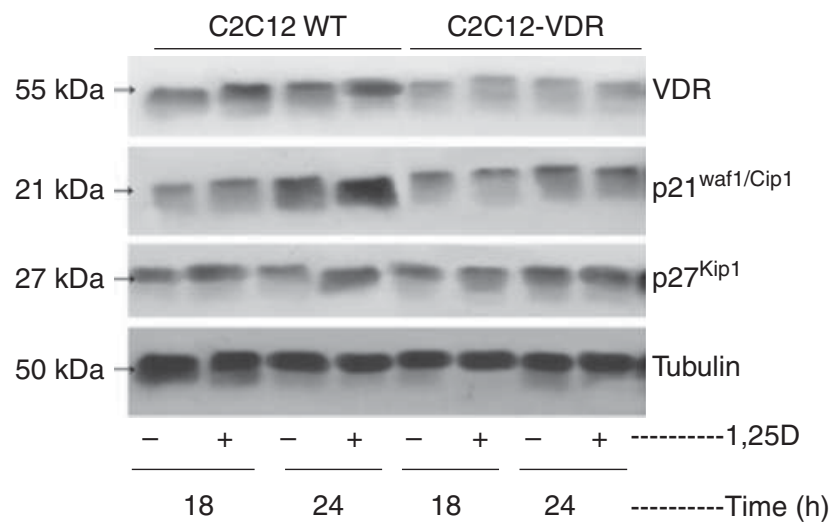

D

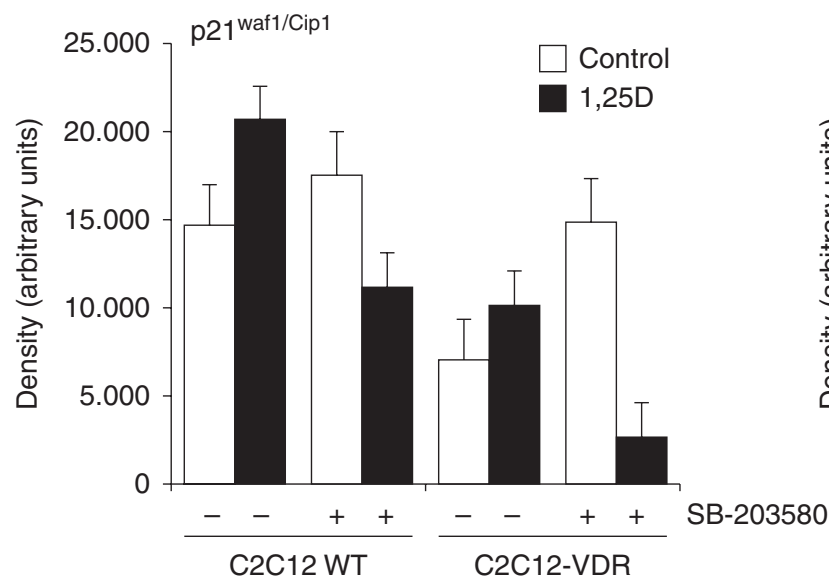

B

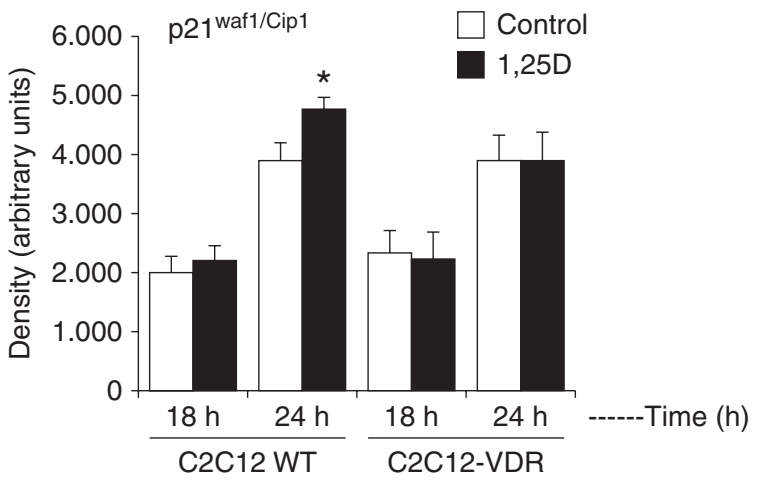

C
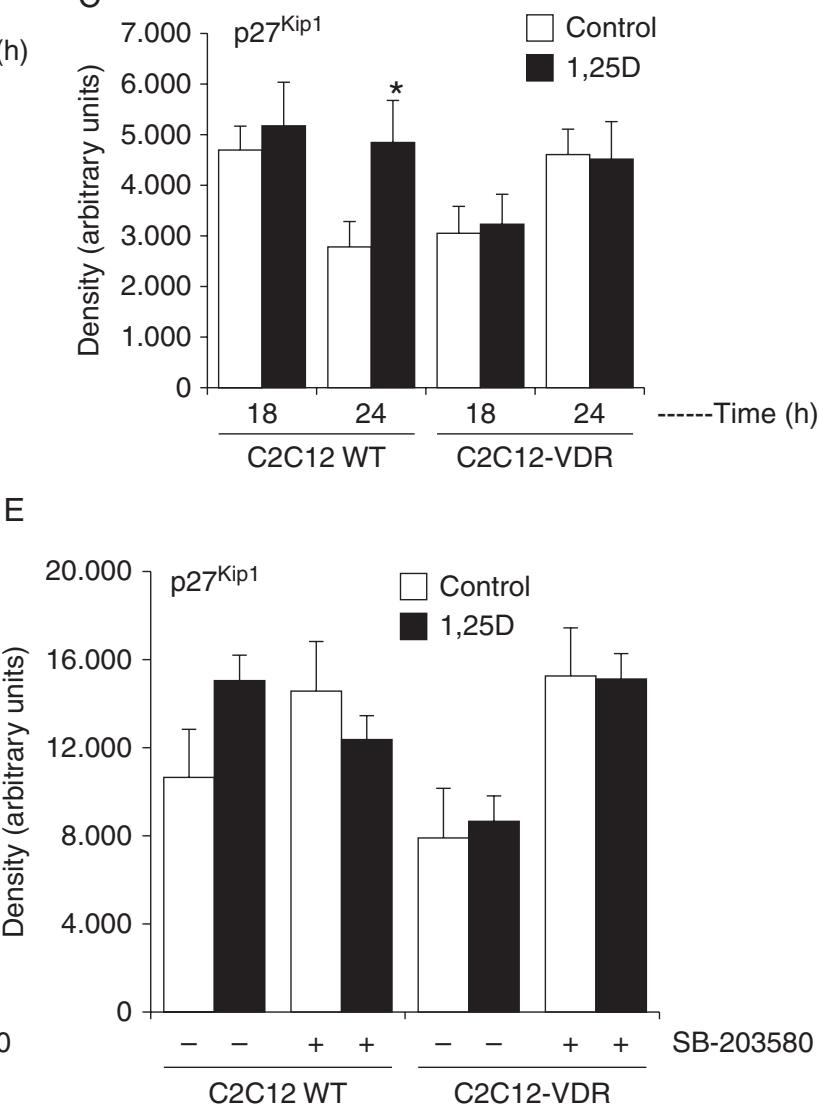

and anti-p2 $7^{\mathrm{Kip} 1}$ protein levels. ${ }^{*} P<0.05$ with respect to the corresponding control. (D and E) C2C12 WT and (-VDR) cells were pre incubated with $10 \mu \mathrm{M}$ SB-203580 and then treated with $1 \mathrm{nM}$ 1,25D or vehicle $(0.001 \%$ isopropanol) for $24 \mathrm{~h}$. Western blotting analysis was carried out using first anti-P-p38, which recognizes only activated p38, and anti-p21 $1^{\text {waf } 1 / \mathrm{Cip} 1}$ and anti-p27 ${ }^{\text {Kip } 1}$ antibodies (data not shown). The blotted membranes were re-probed with anti-p38 $\alpha$ antibody in order to ensure equal loading of gels (data not shown). Immunoblots from four independent experiments were quantified by scanning volumetric densitometry showing mean \pm s.D. of (C) p2 $1^{\text {waf1/Cip } 1}$ protein levels and (D) of p $27^{\text {Kip } 1}$ protein levels. ${ }^{*} P<0.05$ with respect to the corresponding control.

Published by Bioscientifica Ltd. http://jme.endocrinology-journals.org DOI: 10.1530/JME-14-0102
(C) 2014 Society for Endocrinology Printed in Great Britain 


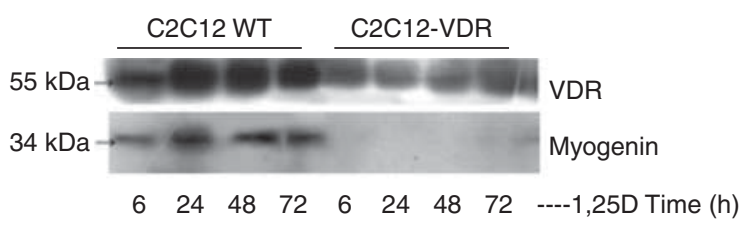

C

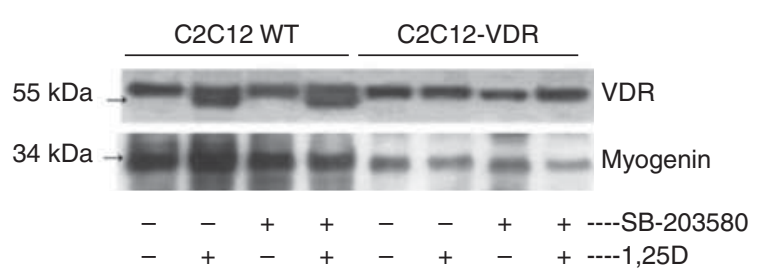

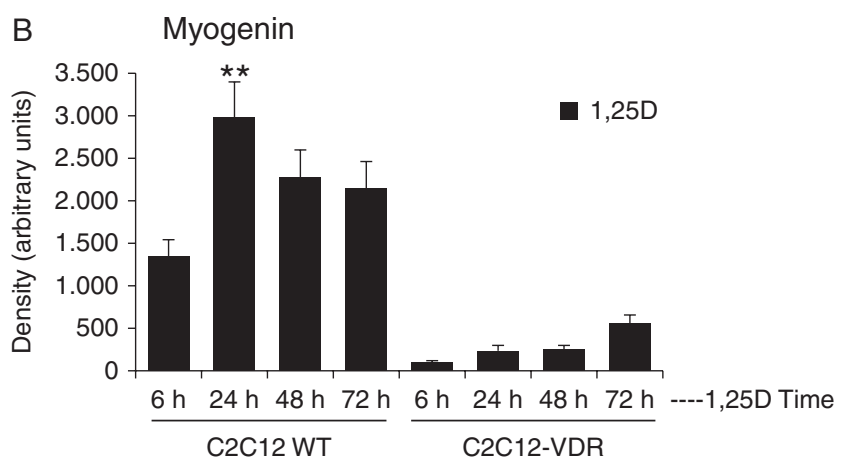

$\mathrm{D}$

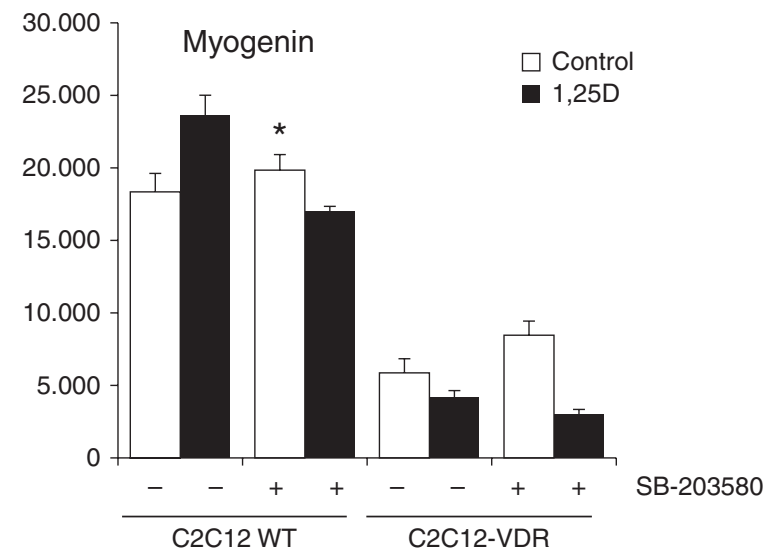

C2C12 WT and C2C12-VDR cells were pre incubated with $10 \mu \mathrm{M}$ of SB-203580 and then treated with $1 \mathrm{nM}$ 1,25D or vehicle $(0.001 \%$ isopropanol) for $24 \mathrm{~h}$. Western blot analysis was carried out using first anti-P-p38, which recognizes only activated p38, and anti-VDR, and anti-myogenin antibodies. The blotted membranes were reprobed with anti-tubulin antibody in order to ensure equal loading of gels (data not shown). Representative immunoblots from three independent experiments are shown (C) and quantifications by scanning volumetric densitometry of blots from three independent experiments showing mean \pm s.D. of cyclin D3 protein levels. ${ }^{*} P<0.05$ with respect to the corresponding control on (D).

participates in VDR and myogenin expression. We successfully performed the silencing of cyclin D3 using siRNA technology in WT C2C12 cells. Figure 7 shows that silencing of cyclin D3 resulted in diminished expression of VDR as well as totally abolishing the induction of myogenin by $1,25 \mathrm{D}$.

\section{Discussion}

C2C12 is a murine highly myogenic myoblastic cell line that remains in the proliferative stage in a medium with 10-20\% FBS, and when these myoblasts become confluent switching them into $2 \%$ horse serum medium, causes them to begin to elongate, become multinucleate, fuse, and finally differentiate into myotubes (Florini et al. 1991). We previously reported that $1,25 \mathrm{D}$ activates the MAPK family http://jme.endocrinology-journals.org DOI: 10.1530/JME-14-0102
(C) 2014 Society for Endocrinology Printed in Great Britain 
A

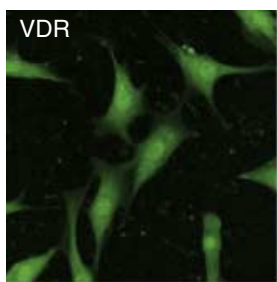

B

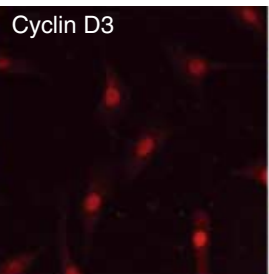

E

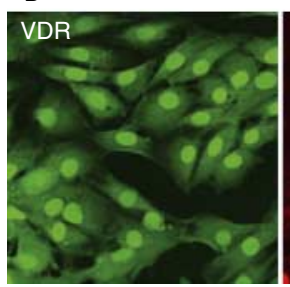

Cyclin D3

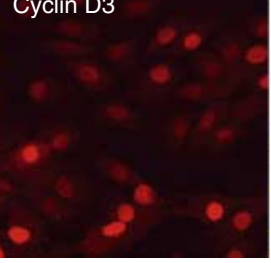

C

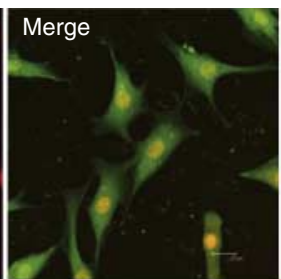

G

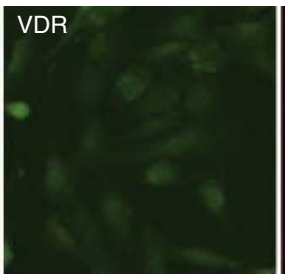

$\mathrm{F}$

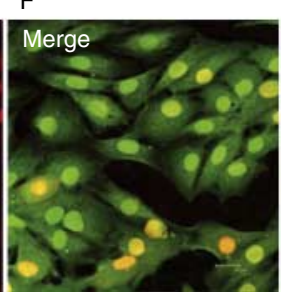

$\mathrm{J}$

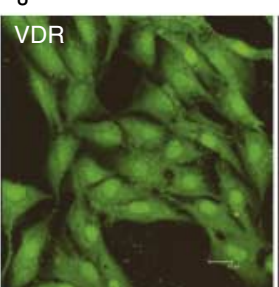

$\mathrm{H}$

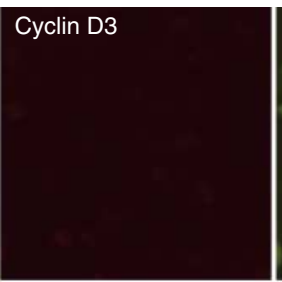

K

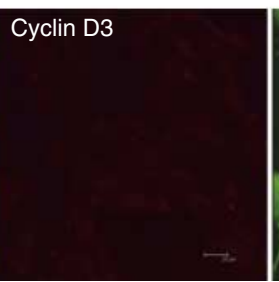

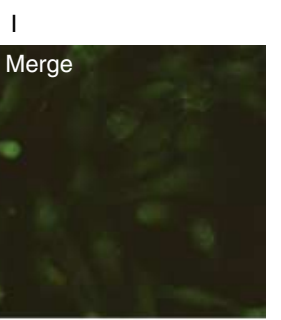

L

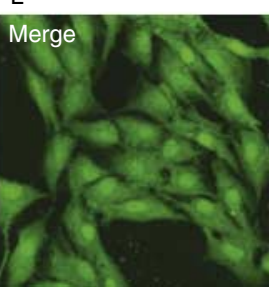

\section{Figure 6}

VDR co-localization with cyclin D3 is dependent on p38 activation. C2C12 WT cells grown on coverslips were stimulated with $1 \mathrm{nM} 1,25 \mathrm{D}$ or vehicle during $24 \mathrm{~h}$, in the presence or absence of SB-203580 (10 $\mu \mathrm{M})$. Immunocytochemistry assays were performed as described in Methods. Confocal fluorescence digital images of C2C12 WT cells incubated with vehicle (panels A, B, and C), 1,25D (panels D, E, and F), SB-203580 (panels G, H,

of proteins in cultured C2C12 myoblasts, thereby influencing the early expression of genes involved in cellular proliferation and differentiation (Ronda et al. 2007). It was observed that for $\mathrm{C} 2 \mathrm{C} 12$ cells (grown in DMEM with $10 \%$ FBS) incubation with $100 \mathrm{nM} 1,25 \mathrm{D}$ stimulated differentiation by inhibiting cell proliferation and modulating the expression of promyogenic growth factors and myostatin (Garcia et al. 2011). However, these results contradict an earlier report that described the downregulation of myogenin and myogenic transcription factor 5 (Myf5) mRNA in C2C12 myoblasts treated with 1,25D for 48 and $96 \mathrm{~h}$ (Endo et al. 2003). It is possible that differences in experimental designs and conditions (e.g. treatment times and concentrations) may account for these contradictory findings. Recently, it was observed that addition of $1,25 \mathrm{D}$ at supraphysiological concentrations $\left(10^{-7}\right.$ and $\left.10^{-5} \mathrm{M}\right)$ appeared to inhibit myotube formation and decreased mRNAs encoding key myogenic regulatory factors (Girgis et al. 2013, Ryan et al. 2013).

In this work, we obtained evidence that VDR expression in $\mathrm{C} 2 \mathrm{C} 12$ cells did not affect the progress of the cell cycle under FBS stimulus. However, it was observed that $1 \mathrm{nM} 1,25 \mathrm{D}$ promotes an increase in the S-phase (at $12 \mathrm{~h}$ ) followed by a G0/G1-phase arrest ( $24 \mathrm{~h}$ ) and that these events decrease in cells lacking VDR, showing a dual effect of 1,25D. In view of our previous results (Buitrago et al. 2012), it was expected that a cell proliferative state would be observed at $24 \mathrm{~h}$. This may be explained by and I), SB-203580 and 1,25D (panels J, K, and L) and double labeled with anti-VDR antibody (green), and anti-cyclin D3 antibody (red) are shown. White bars in images represent $20 \mu \mathrm{m}$. The right side of each panel shows merged microphotograghs. Representative images of different fields of all coverslips analyzed are shown. A full colour version of this figure is available via http://dx.doi.org/10.1530/JME-14-0102.

the fact that now the cells were deprived of serum for $16 \mathrm{~h}$, instead of $2 \mathrm{~h}$ as reported previously. Okuno et al. (2012) have observed that stimulation of $\mathrm{C} 2 \mathrm{C} 12$ cells with $1,25 \mathrm{D}$ in presence of $10 \% \mathrm{FBS}$ for $72 \mathrm{~h}$ induced an increase in the percentage of cells in the G0/G1-phase in the absence of a proliferative stimulus from the hormone. The $1,25 \mathrm{D}$ inhibition of proliferation of myoblasts grown in DMEM

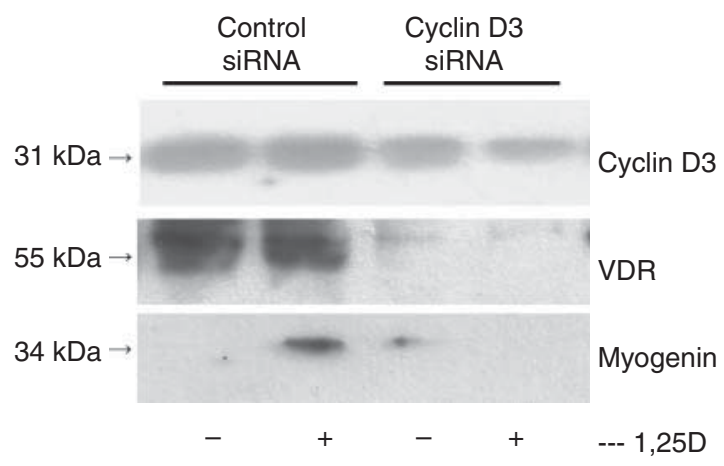

Figure 7

Silencing of cyclin D3 by a specific siRNA affects VDR and myogenin expression in muscle cells. C2C12 WT cells were transfected with 50 pmol cyclin D3 siRNA or control siRNA for $6 \mathrm{~h}$ according to the manufacturer's specifications. Transfected cells were incubated for an additional $18 \mathrm{~h}$ period in fresh medium until treatments were administered (as indicated previously). Western blot analyses were carried out with anti-cyclin D3, anti-VDR, and anti-myogenin antibodies. The blotted membranes were reprobed with anti-tubulin antibody in order to ensure equal loading of gels (data not shown). Representative immunoblots of blots from two independent experiments are shown. 
with 10\% FBS was in addition reported by Srikuea et al. (2012), who also demonstrated VDR expression in C2C12 cells. The authors used $20 \mathrm{nM}$ of 1,25D for $48 \mathrm{~h}$ and under these conditions, they observed an increase in VDR expression and a significant decrease in the number of cells (Srikuea et al. 2012).

We also demonstrated that p38 participates in 1,25D-dependent G0/G1-phase arrest in C2C12 cells. In agreement with these data, it has been previously shown that p38 activation results in G1-phase arrest and differentiation (Puri et al. 2000). Moreover, our data indicate that VDR and p38 participate in hormone up-regulation of cyclin D3 protein levels. The relationship between cyclin D3 and VDR has been previously reported. Cyclin D3 interacts with VDR and, in this way, regulates its transcriptional activity, and ligand-activated VDR induces an accumulation of cyclin D3 in the nuclear region (Jian et al. 2005). In this study, it was shown that 1,25D-induced VDR expression was abolished when cyclin D3 was silenced by siRNA. Cyclin D3 is a target gene downstream of p38 in hepatic cells (Sun et al. 2013), and in $\mathrm{C} 2 \mathrm{C} 12$ cells evidence has been obtained that silencing of specific p38 isoforms affects cyclin D3 expression (Wang et al. 2008). It is of relevance that evidence of the participation of p38 in cyclin D3 expression induced by $1,25 \mathrm{D}$ is reported for the first time, to our knowledge, in this work. In addition, we obtained evidence that $1,25 \mathrm{D}$ induces the co-localization between VDR and cyclin D3 in a p38-dependent manner. In $\mathrm{C} 2 \mathrm{C} 12$ cells, an increase in cyclin D3 levels promotes myogenic differentiation (Gurung \& Parnaik 2012) and cyclin D3 is also greatly induced at later stage differentiating cells (Kiess et al. 1995). In skeletal muscle cells, the differentiation process is accompanied by a decrease in cyclin D1 expression (Rao $\&$ Kohtz 1995). However, our results showed no significant changes in cyclin D1 levels in C2C12 cells stimulated with $1,25 \mathrm{D}$. The fact that the hormone promotes a G0/G1-phase arrest of C2C12 myoblasts without changes in cyclin D1 protein would indicate that it does not require this cyclin in particular to carry out its actions.

Given that differentiation of skeletal muscle precursor cells is always accompanied by an increase in cyclin D3 expression, as we observed in WT C2C12 cells, we propose the hypothesis that the VDR- and p38-dependent arrest in the G0/G1-phase is a pro-differentiative event. 1,25D regulation of chick myoblast differentiation was described for the first time in our laboratory (Capiati et al. 1999). Later, it was demonstrated that the VDR is necessary for normal skeletal muscle development and the correct expression of myoregulatory transcription factors in mice (Endo et al. 2003). Moreover, we have previously shown that the hormone induces myosin heavy chain (MHC) and myogenin in the early stage of differentiation of $\mathrm{C} 2 \mathrm{C} 12$ cells grown in low-serum medium (Buitrago et al. 2012). The presence of myogenin ensures MHC expression and modulates the subsequent myotube development, demonstrating that myogenin acts early in the determination of myoblast differentiation (Davie et al. 2007). In this work, $1,25 \mathrm{D}$ induced an acute and steady increase in myogenin expression in C2C12 WT cells, while myogenin protein levels remained undetectable in $\mathrm{C} 2 \mathrm{C} 12$ VDR cells and when p38 was inhibited. Moreover, we obtained evidence that in $\mathrm{C} 2 \mathrm{C} 12$ cells transfected with a siRNA against cyclin D3 mRNA, myogenin expression is abolished. This clearly shows that the beginning of the differentiation program induced by $1,25 \mathrm{D}$ in $\mathrm{C} 2 \mathrm{C} 12$ cells requires the expression of the VDR and activation of $\mathrm{p} 38$. However, in cyclin D3-deficient C2.7 myoblasts, changes in myogenin expression were not found (De Luca et al. 2013). This may be explained by differences in experimental design (like the use of differentiation medium) or other pathways which are not regulated by $1,25 \mathrm{D}$ being involved in myogenin expression.

Both P21 ${ }^{\text {waf1/Cip } 1}$ and $\mathrm{p} 27^{\mathrm{Kip} 1}$ are CKIs; however, they have specific actions in myogenic differentiation (el-Deiry et al. 1994, Guo et al. 1994). The induction of $\mathrm{p} 27^{\mathrm{Kip} 1}$ CKI is an early critical step of the $\mathrm{N}$-cadherin-dependent signaling involved in myogenesis, showing an active role of p27 ${ }^{\mathrm{Kip} 1} \mathrm{CKI}$ in the decision of myoblasts to undergo differentiation (Messina et al. 2005). It is of relevance that when C2C12 myoblasts start expressing CKI, p21 $1^{\text {waf1/Cip } 1}$ (Andres \& Walsh 1996) and p27 ${ }^{\text {Kip1 }}$ (Franklin \& Xiong 1996), they withdraw from the cell cycle and become determined to be differentiated into mature muscle cells. In this study, we showed that $1,25 \mathrm{D}$ increases protein levels of $\mathrm{p} 21^{\text {waf1/Cip } 1}$ and $\mathrm{p} 27^{\text {Kip } 1}$ CKIs during G0/G1-phase arrest in a VDR- and p38-dependent manner. In accordance with these results, $1,25 \mathrm{D}$ has been shown to upregulate CKIs, p2 $1^{\text {waf1/Cip1 }}$ and $\mathrm{p} 27^{\mathrm{Kip} 1}$, expression (Verlinden et al. 1998) and, more interestingly the CKI $p 21^{\text {wafl/Cip } 1}$ gene was identified as a transcriptional target of VDR (Freedman 1999), with a functional VDRE being recognized in its promoter (Liu et al. 1996). In vascular smooth muscle cells, p38 mediates transcription of the CKI p21 $21^{\text {wafl/Cip } 1}$ gene (Moon et al. 2004). However, participation of p38 in 1,25D-induced CKI p21 $1^{\text {waf1/Cip1 }}$ protein expression has not, to our knowledge, been reported previously. With respect to $\mathrm{p} 27^{\mathrm{Kip} 1}$, the VDR functions as the transactivation component of the VDR-Sp1 complex to trigger the expression of its gene

Published by Bioscientifica Ltd. 
(Cheng et al. 2006). Also, 1,25D-upregulation of CKI $\mathrm{p} 27^{\mathrm{Kip} 1}$ is blocked by a p38 inhibitor (Miura et al. 2005). Similarly to CKI p21 $1^{\text {waf1/Cip } 1}$, this is the first report, to our knowledge, showing that $1,25 \mathrm{D}$ induces CKI p27 ${ }^{\mathrm{Kip} 1}$ with the involvment of p38.

\section{Conclusions}

We conclude that in the 1 1 ,25-dihydroxyvitamin $\mathrm{D}_{3}$ induced differentiation of $\mathrm{C} 2 \mathrm{C} 12$ cells the VDR and p38 are significantly involved, leading to G0/G1 arrest of cells accompanied by cyclin D3-augmented expression and elevated levels of CKIs, p21 waf1/Cip1 and p27 ${ }^{\mathrm{kip} 1}$. Moreover, $1,25 \mathrm{D}$ promotes a p38-dependent co-localization of VDR and cyclin D3 and this cyclin is required in 1,25D-induced expression of VDR and myogenin. Our findings help to elucidate the mechanism by which the hormone contributes to the differentiation of myoblasts, which accounts for its effects on skeletal muscle growth and regeneration, revealing an important role of the VDR and p38 in the physiological actions of $1,25 \mathrm{D}$ on skeletal muscle.

\section{Declaration of interest}

The authors declare that there is no conflict of interest that could be perceived as prejudicing the impartiality of the research reported.

\section{Funding}

This research was supported by grants from the Agencia Nacional de Promoción Científica y Técnica and Universidad Nacional del Sur, Argentina.

\section{Acknowledgements}

The authors thank Gastón Stockman for his assistance with flow cytometric analyses.

\section{References}

Andres V \& Walsh K 1996 Myogenin expression, cell cycle withdrawal, and phenotypic differentiation are temporally separable events that precede cell fusion upon myogenesis. Journal of Cell Biology 132 657-666. (doi:10.1083/jcb.132.4.657)

Aslam F, McCabe L, Frenkel B, van Wijnen AJ, Stein GS, Lian JB \& Stein JL 1999 AP-1 and vitamin D receptor (VDR) signaling pathways converge at the rat osteocalcin VDR element: requirement for the internal activating protein-1 site for vitamin D-mediated trans-activation. Endocrinology 140 63-70. (doi:10.1210/endo.140.1.6429)

Buitrago CG, Arango NS \& Boland RL $20121 \alpha, 25(\mathrm{OH})_{2} \mathrm{D}_{3}$-dependent modulation of Akt in proliferating and differentiating C2C12 skeletal muscle cells. Journal of Cellular Biochemistry 113 1170-1181. (doi:10.1002/jcb.23444)

Buitrago C, Pardo VG \& Boland R 2013 Role of VDR in 1 $\alpha, 25$ dihydroxyvitamin $\mathrm{D}_{3}$-dependent non-genomic activation of MAPKs, Src and Akt in skeletal muscle cells. Journal of Steroid Biochemistry and Molecular Biology 136 125-130. (doi:10.1016/j.jsbmb.2013.02.013)
Cabane C, Englaro W, Yeow K, Ragno M \& Dérijard B 2003 Regulation of C2C12 myogenic terminal differentiation by MKK3/p38 $\alpha$ pathway. American Journal of Physiology. Cell Physiology 284 C658-C666. (doi:10.1152/ajpcell.00078.2002)

Campbell MJ 2014 Vitamin D and the RNA transcriptome: more than mRNA regulation. Frontiers in Physiology 14 175-181. (doi:10.3389/ fphys.2014.00181)

Capiati DA, Téllez-Iñón MT \& Boland RL 1999 Participation of protein kinase $\mathrm{C} \alpha$ in 1,25-dihydroxy-vitamin $\mathrm{D}_{3}$ regulation of chick myoblast proliferation and differentiation. Molecular and Cellular Endocrinology 153 39-45. (doi:10.1016/S0303-7207(99)00093-3)

Cenciarelli C, De Santa F, Puri P, Mattei E, Ricci L, Bucci F, Felsani A \& Caruso M 1999 Critical role played by cyclin D3 in the MyoD-mediated arrest of cell cycle during myoblast differentiation. Molecular and Cellular Biology 19 5203-5217.

Chellappan S, Giordano A \& Fisher A 1998 Role of cyclin-dependent kinases and their inhibitors in cellular differentiation and development. Current Topics in Microbiology and Immunology 227 57-103. (doi:10.1007/978-3-642-71941-7_4)

Cheng HT, Chen JY, Huang YC, Chang HC \& Hung WC 2006 Functional role of VDR in the activation of $\mathrm{p} 27^{\mathrm{Kip} 1}$ by the VDR/Sp1 complex. Journal of Cellular Biochemistry 98 1450-1456. (doi:10.1002/jcb.20780)

Clemente C, Corat MA, Saad ST \& Franchini KG 2005 Differentiation of $\mathrm{C}_{2} \mathrm{C}_{12}$ myoblasts is critically regulated by FAK signaling. American Journal of Physiology. Regulatory, Integrative and Comparative Physiology 289 862-870. (doi:10.1152/ajpregu.00348.2004)

Cuenda A \& Cohen P 1999 Stress-activated protein kinase-2/p38 and a rapamycin-sensitive pathway are required for C2C12 myogenesis. Journal of Biological Chemistry 274 4341-4346. (doi:10.1074/ jbc.274.7.4341)

Davidovic L, Durand N, Khalfallah O, Tabet R, Barbry P, Mari B, Sacconi S, Moine H \& Bardoni B 2013 A novel role for the RNA-binding protein FXR1P in myoblasts cell-cycle progression by modulating p21/Cdkn1a/Cip1/Waf1 mRNA stability. PLoS Genetics 9 e1003367. (doi:10.1371/journal.pgen.1003367)

Davie JK, Cho JH, Meadows E, Flynn JM, Knapp JR \& Klein WH 2007 Target gene selectivity of the myogenic basic helix-loop-helix transcription factor myogenin in embryonic muscle. Developmental Biology 311 650-664. (doi:10.1016/j.ydbio.2007.08.014)

el-Deiry WS, Harper JW, O'Connor PM, Velculescu VE, Canman CE, Jackman J, Pietenpol JA, Burrell M, Hill DE, Wang Y et al. 1994 WAF1/CIP1 is induced in p53-mediated G1 arrest and apoptosis. Cancer Research 54 1169-1174.

De Luca G, Ferretti R, Bruschi M, Mezzaroma E \& Caruso M 2013 Cyclin D3 critically regulates the balance between self-renewal and differentiation in skeletal muscle stem cells. Stem Cells 31 2478-2491. (doi:10.1002/ stem.1487)

Endo I, Inoue D, Mitsui T, Umaki Y, Akaike M, Yoshizawa T, Kato S \& Matsumoto T 2003 Deletion of vitamin D receptor gene in mice results in abnormal skeletal muscle development with deregulated expression of myoregulatory transcription factors. Endocrinology 144 5138-5144. (doi:10.1210/en.2003-0502)

Ertesvag A, Aasheim HC, Naderi S \& Blomhoff HK 2007 Vitamin A potentiates CpG-mediated memory B-cell proliferation and differentiation: involvement of early activation of p38MAPK. Blood 109 3865-3872. (doi:10.1182/blood-2006-09-046748)

Florini JR, Ewton EZ \& Magri KA 1991 Hormones, growth factors, and myogenic differentiation. Annual Review of Physiology 53 201-216. (doi:10.1146/annurev.ph.53.030191.001221)

Franklin DS \& Xiong Y 1996 Induction of p $18^{I N K 4 c}$ and its predominant association with CDK4 and CDK6 during myogenic differentiation. Molecular Biology of the Cell 7 1587-1599. (doi:10.1091/mbc.7.10.1587)

Freedman LP 1999 Transcriptional targets of the vitamin $\mathrm{D}_{3}$ receptor-mediating cell cycle arrest and differentiation. Journal of Nutrition 129 581S-586S.

Garcia LA, King KK, Ferrini MG, Norris KC \& Artaza JN 2011 1,25(OH) vitamin $\mathrm{D}_{3}$ stimulates myogenic differentiation by inhibiting cell 
proliferation and modulating the expression of promyogenic growth factors and myostatin in C2C12 skeletal muscle cells. Endocrinology 152 2976-2986. (doi:10.1210/en.2011-0159)

Girgis CM, Clifton-Bligh RJ, Mokbel N, Cheng K \& Gunton JE 2013 Vitamin D signaling regulates proliferation, differentiation and myotube size in C2C12 skeletal muscle cells. Endocrinology 155 347-357. (doi:10.1210/en.2013-1205)

Guo K, Wang J, Andres V, Smith RC \& Walsh K 1994 MyoD induced expression of p21 inhibits cyclin-dependent kinase activity upon myocyte terminal differentiation. Molecular and Cellular Biology 15 3823-3829. (doi:10.1161/01.CIR.97.20.2066)

Gurung R \& Parnaik VK 2012 Cyclin D3 promotes myogenic differentiation and Pax7 transcription. Journal of Cellular Biochemistry 13 209-219. (doi:10.1002/jcb.23346)

Jahn L, Sadoshima J \& Izumo S 1994 Cyclins and cyclin-dependent kinases are differentially regulated during terminal differentiation of $\mathrm{C} 2 \mathrm{C} 12$ muscle cells. Experimental Cell Research 212 297-307. (doi:10.1006/excr. 1994.1147)

Jensen LJ, Jensen TS, de Lichtenberg U, Brunak S \& Bork P 2006 Co-evolution of transcriptional and post-translational cell-cycle regulation. Nature 443 594-597. (doi:10.1038/nature05186)

Jian Y, Yan J, Wang H, Chen C, Sun M, Jiang J, Lu J, Yang Y \& Gu J 2005 Cyclin D3 interacts with vitamin D receptor and regulates its transcription activity. Biochemical and Biophysical Research Communications 335 739-748. (doi:10.1016/j.bbrc.2005.07.141)

Kiess M, Gill RM \& Hamel PA 1995 Expression of the positive regulator of cell cycle progression, cyclin D3, is induced during differentiation of myoblasts into quiescent myotubes. Oncogene 10 159-166.

Kim JY, Choi JA, Kim TH, Yoo YD, Kim JI, Lee YJ, Yoo SY, Cho CK, Lee YS \& Lee SJ 2002 Involvement of p38 mitogen-activated protein kinase in the cell growth inhibition by sodium arsenite. Journal of Cellular Physiology 190 29-37. (doi:10.1002/jcp.10049)

Kumar S, McDonnell PC, Gum RJ, Hand AT, Lee JC \& Young PR 1997 Novel homologues of CSBP/p38 MAP kinase: activation, substrate specificity and sensitivity to inhibition by pyridinyl imidazoles. Biochemical and Biophysical Research Communications 235 533-538. (doi:10.1006/bbrc. 1997.6849)

Lee J, Hong F, Kwon S, Kim SS, Kim DO, Kang HS, Lee SJ, Ha J \& Kim SS 2002 Activation of p38 MAPK induces cell cycle arrest via inhibition of Raf/ERK pathway during muscle differentiation. Biochemical and Biophysical Research Communications 298 765-771. (doi:10.1016/S0006-291X(02)02562-7)

Liu MM, Lee M, Cohen M, Bommakanti M \& Freedman L 1996 Transcriptional activation of the Cdk inhibitor $\mathrm{p} 21$ by vitamin $\mathrm{D}_{3}$ leads to the induced differentiation of the myelomonocytic cell line U937. Genes and Development 10 142-153. (doi:10.1101/gad.10.2.142)

Lluís F, Ballestar E, Suelves M, Esteller M \& Muñoz-Cánoves P 2005 E47 phosphorylation by p38 MAPK promotes MyoD/E47 association and muscle-specific gene transcription. EMBO Journal 24 974-984. (doi:10.1038/sj.emboj.7600528)

MacDonald P, Baudino TA, Tokumaru H, Dowd DR \& Zhang C 2001 Vitamin D receptor and nuclear receptor coactivators: crucial interactions in vitamin D-mediated transcription. Steroids 66 171-176. (doi:10.1016/S0039-128X(00)00200-2)

Mercer S, Ewton DZ, Deng X, Lim S, Mazur TR \& Friedman E 2005 Mirk/Dyrk1B mediates survival during the differentiation of C2C12 myoblasts. Journal of Biological Chemistry 280 25788-25801. (doi:10.1074/jbc.M413594200)

Messina G, Blasi C, La Rocca SA, Pompili M, Calconi A \& Grossi M 2005 $\mathrm{p} 27^{\mathrm{Kip} 1}$ acts downstream of N-cadherin-mediated cell adhesion to promote myogenesis beyond cell cycle regulation. Molecular Biology of the Cell 16 1469-1480. (doi:10.1091/mbc.E04-07-0612)

Miura S, Matsuo Y, Kawamura A \& Saku K 2005 JTT-705 blocks cell proliferation and angiogenesis through $\mathrm{p} 38$ kinase $/ \mathrm{p} 27^{\mathrm{kip} 1}$ and
Ras/p21 waf1 pathways. Atherosclerosis 182 267-275. (doi:10.1016/ j.atherosclerosis.2005.02.017)

Moon SK, Jung SY \& Kim CH 2004 Transcription factor Sp1 mediates p38MAPK-dependent activation of the p21WAF1 gene promoter in vascular smooth muscle cells by pyrrolidine dithiocarbamate. Biochemical and Biophysical Research Communications 316 605-611. (doi:10.1016/j.bbrc.2004.02.096)

Morelli S, Buitrago C, Boland R \& de Boland A 2001 The stimulation of MAP kinase by $1,25(\mathrm{OH})_{2}$-vitamin $\mathrm{D}_{3}$ in skeletal muscle cells is mediated by protein kinase $\mathrm{C}$ and calcium. Molecular and Cellular Endocrinology 173 41-52. (doi:10.1016/S0303-7207(00)00435-4)

Nakano N, Urasawa K, Takagi Y, Saito T, Kaneta S, Ishikawa S, Higashi H, Tsutsui H, Hatakeyama M \& Kitabatake A 2005 Downregulation of cyclin-dependent kinase inhibitor; p5 $7^{\mathrm{kip} 2}$, is involved in the cell cycle progression of vascular smooth muscle cells. Biochemical and Biophysical Research Communications 338 1661-1667. (doi:10.1016/j.bbrc.2005.10.093)

Okuno H, Kishimoto KN, Hatori M \& Itoi E 2012 1 $\alpha, 25$-dihydroxyvitamin $\mathrm{D}_{3}$ enhances fast-myosin heavy chain expression in differentiated $\mathrm{C} 2 \mathrm{C} 12$ myoblasts. Cell Biology International 36 441-447. (doi:10.1042/CBI20100782)

Puri PL, Wu Z, Zhang P, Wood LD, Bhakta KS, Han J, Feramisco JR, Karin M \& Wang JY 2000 Induction of terminal differentiation by constitutive activation of p38 MAP kinase in human rhabdomyosarcoma cells. Genes and Development 14 574-584. (doi:10.1101/gad.14.5.574)

Rao S \& Kohtz DS 1995 Positive and negative regulation of D-type cyclin expression in skeletal myoblasts by basic fibroblast growth factor and transforming growth factor $\beta$. A role for cyclin D1 in control of myoblast differentiation. Journal of Biological Chemistry $2704093-4100$. (doi:10.1074/jbc.270.8.4093)

Ronda AC, Buitrago C, Colicheo A, de Boland A, Roldan E \& Boland R 2007 Activation of MAPKs by $1,25(\mathrm{OH})_{2}$-vitamin $\mathrm{D}_{3}$ and 17 -estradiol in skeletal muscle cells leads to phosphorylation of Elk-1 and CREB transcription factors. Journal of Steroid Biochemistry and Molecular Biology 103 462-466. (doi:10.1016/j.jsbmb.2006.11.005)

Ryan KJ, Daniel ZC, Craggs LJ, Parr T \& Brameld JM 2013 Dose-dependent effects of vitamin D on transdifferentiation of skeletal muscle cells to adipose cells. Journal of Endocrinology 217 45-58. (doi:10.1530/JOE-12-0234)

Snedecor G \& Cochran GW 1967. Statistical Methods, Ames, IA: Iowa State University Press.

Srikuea R, Zhang X, Park-Sarge OK \& Esser KA 2012 VDR and CYP27B1 are expressed in C2C12 cells and regenerating skeletal muscle: potential role in suppression of myoblast proliferation. American Journal of Physiology. Cell Physiology 303 396-405. (doi:10.1152/ajpcell.00014.2012)

Sun Y, Tang S, Jin X, Zhang C, Zhao W \& Xiao X 2013 Involvement of the p38 MAPK signaling pathway in S-phase cell-cycle arrest induced by Furazolidone in human hepatoma G2 cells. Journal of Applied Toxicology 33 1500-1505. (doi:10.1002/jat.2829)

Verlinden L, Verstuyf A, Convents R, Marcelis S, Van Camp M \& Bouillon R 1998 Action of $1,25(\mathrm{OH})_{2} \mathrm{D}_{3}$ on the cell cycle genes, cyclin D1, p21 and p27 in MCF-7 cells. Molecular and Cellular Endocrinology 142 57-65. (doi:10.1016/S0303-7207(98)00117-8)

Wang J \& Nadal-Ginard B 1995 Regulation of cyclins and p34 ${ }^{\mathrm{CDC} 2}$ expression during terminal differentiation of C2C12 myocytes. Biochemical and Biophysical Research Communications 206 82-88. (doi:10.1006/bbrc.1995.1012)

Wang H, Xu Q, Xiao F, Jiang Y \& Wu Z 2008 Involvement of the p38 mitogen-activated protein kinase $\alpha, \beta$, and $\gamma$ isoforms in myogenic differentiation. Molecular Biology of the Cell 19 1519-1528. (doi:10.1091/mbc.E07-08-0817)

Zetser A, Gredinger E \& Bengal E 1999 p38 mitogen-activated protein kinase pathway promotes skeletal muscle differentiation. Participation of the Mef2c transcription factor. Journal of Biological Chemistry 274 5193-5200. (doi:10.1074/jbc.274.8.5193)

Received in final form 19 August 2014

Accepted 4 September 2014 http://jme.endocrinology-journals.org DOI: 10.1530/JME-14-0102
(C) 2014 Society for Endocrinology Printed in Great Britain 